\title{
Rural Electrification Design and Simulation Based on the use of Stand-alone Photovoltaic Micro-grid
}

\author{
Ayibapreye Kelvin Benjamin *, Christopher Akemi**, Aguiyi Watson ${ }^{* * *}$ \\ * Department of Electrical/Electronic Engineering, Niger Delta University, Wilberforce Island, Bayelsa State \\ ** Department, of Electrical/Electronic Engineering, Niger Delta University, Bayelsa State \\ ${ }^{* * * *}$ Federal University Otueke, Bayelsa State
}

DOI: 10.29322/IJSRP.11.12.2021.p12014

http://dx.doi.org/10.29322/IJSRP.11.12.2021.p12014

\begin{abstract}
This paper reports the design and simulation of a stand-alone solar powered photovoltaic direct current (DC) micro-grid for Lobia community in Southern Ijaw Local Government Area of Bayelsa State. This was done to bridge the gaps in shortage or lack of power supply in remote communities that have no access to the national grid. Rural communities that have no access to the national grid often face poor social, economic and technological growth. Lobia has roughly 800 dwellings and a number of communal installations such as churches, schools, stores, and a water pumping system. To meet the all-time load demand, the proper sizes of system components are determined. The community's energy demand was calculated to be $3.16 \mathrm{MWh} / \mathrm{day}$. Here, the battery storage system was also sized, and a battery system with a capacity of 21,944Ah was able to cover the community's energy needs for up to a day without the use of renewable energy. The proposed stand-alone PV-based DC micro-grid model was simulated in the MATLAB/SIMULINK environment to examine the system's dynamic response in terms of power quality, load impact, and battery storage charging. The simulation findings showed a stand-alone DC micro-grid capable of supplying the system's daily electrical energy requirements while maintaining good voltage stability. In unfavourable weather conditions, the PV system used in the system could operate at maximum power.
\end{abstract}

Index Terms- Rural electrification, Stand-alone solar photovoltaic, DC microgrid, design and simulation.

\section{INTRODUCTION}

M ajority of rural areas in Nigeria have been without power from the national grid. This is primarily due to a lack of access to these areas, which translates into high grid installation costs. There are an estimated 1.5 billion people in the world who do not have access to electricity [1]. As a result, these communities have resorted to using local methods to meet their lighting, heating, and cooking requirements. This, in turn, has a negative impact on their financial stability. Most of the time, these places offer ample renewable energy resources such as wind, solar, and hydro, which are inexpensive and environmentally friendly sources of energy. As a result, it is suggested that various energy sources be investigated in order to give electricity to these rural areas. The AC microgrid and the DC microgrid are the two types of microgrids.

A DC microgrid was proposed for this community for a variety of reasons, including ease of integration with renewable energy sources and storage [2], availability of most DC load [3], loss reduction due to fewer conversion stages [4], low distribution cost, and low system complexity. A Solar PV based DC microgrid will be an efficient way to generate stable and cheap electricity for the community due to the lack of grid in Lobia since its inception and the very high availability of solar energy resource that can be harnessed for isolated microgrid.

In recent years, the DC micro-grid technology has become increasingly important. Developed countries are conducting research in this field in order to change the way buildings are electrified. DC electrification is being considered not only for rural areas, but also for urban structures. DC electrification is not a new concept; it was in use prior to the arrival of AC because the electrical load was DC. AC electrification was affected by the emergence of complex appliances such as air conditioning, AC (Alternative Current) motors, and long-range power transmission. The number of appliances that work on DC is steadily increasing, and new ones are being developed all the time.

The majority of electronic appliances we use today, such as laptops, computers, televisions, and so on, require DC to operate. These appliances take AC and convert it to low voltage DC using the adaptors that come with them. If the electrification is DC, this conversion can be avoided. Due to technological advancement, we now have LED lights, which work by converting AC to DC with a sufficient working voltage because majority of the appliances we use daily depends on DC power to operate such as light bulbs. The power loss associated with converting AC to DC is one of the most significant issues. 
As a result of these drawbacks, DC power networks and small grids are being considered as a possible alternative to AC grid for electrification in developing countries.

\section{RESEARCH METHODOLOGY}

This phase of the project will focus on the system sizing and description of a stand-alone micro-grid for rural electrification, with MATLAB/SIMULINK utilized to visualize the results.

\subsection{System Sizing}

The precise delivery of power to clients is critical in power generation and distribution. As a result, a power system that matches the energy needs of customers is required. The design and simulation of a stand-alone DC micro-grid that would deliver power to 800 households in a remote location of Nigeria are part of this study. This section of the study will go through the specifics of:

* Accurate measurement of the load profile of the community.

- Optimal sizing of the power system.

* Community Load Profile.

Daily Profile

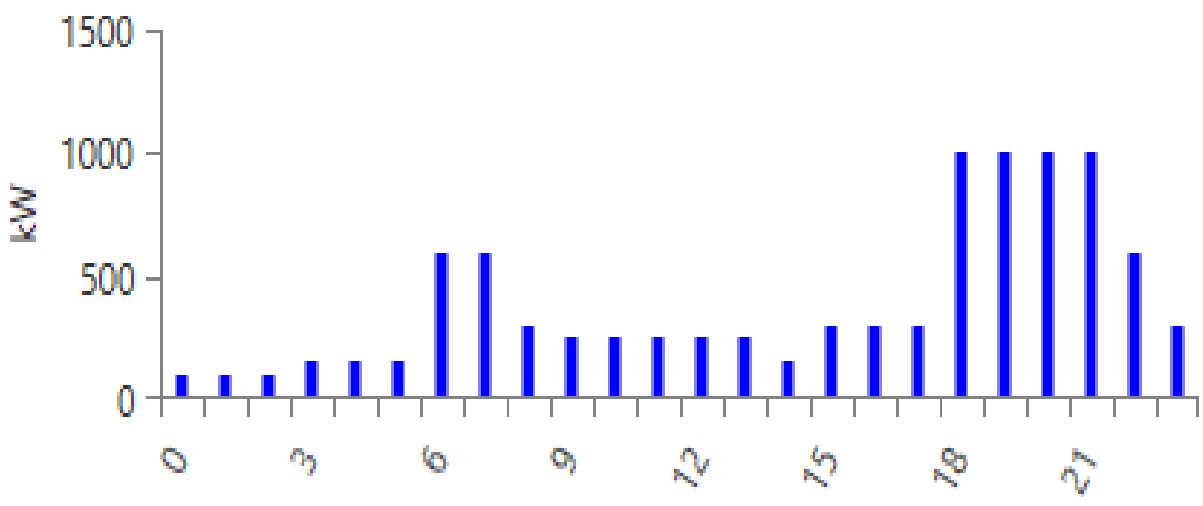

Figure 1: Daily Load Profile of LOBIA 


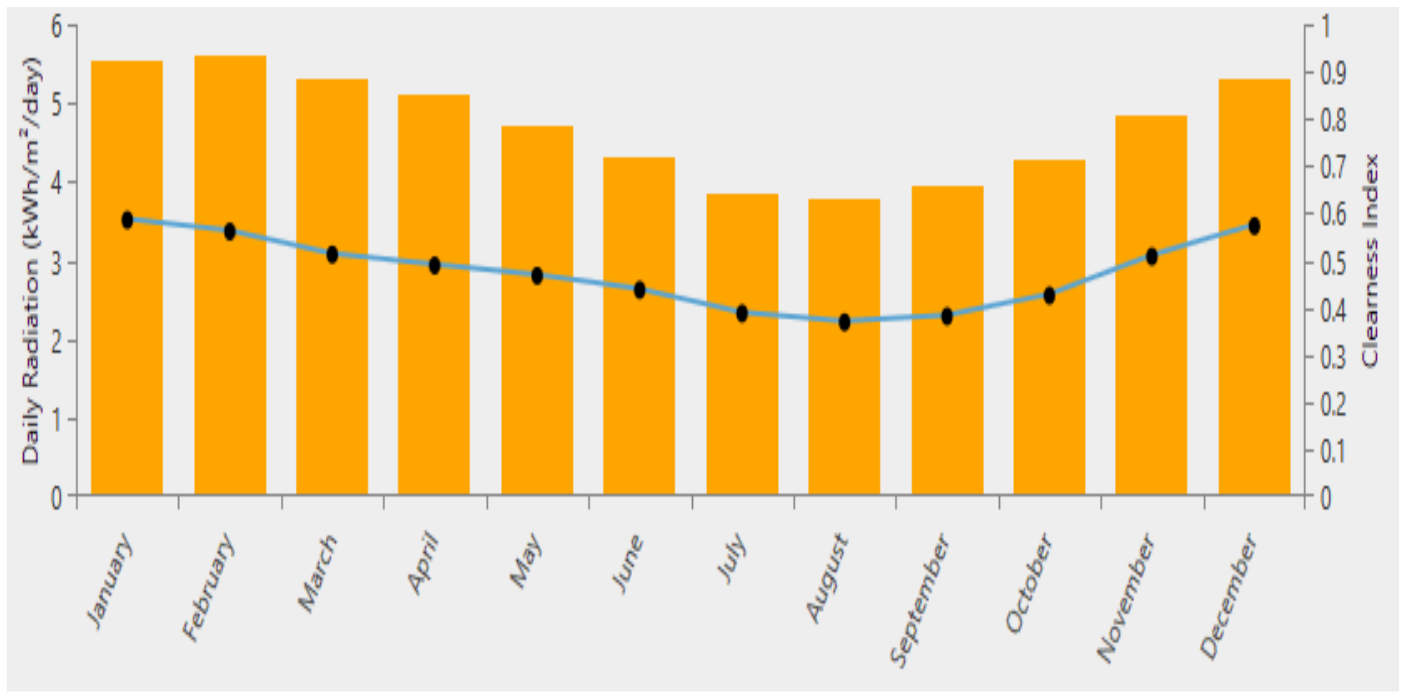

Figure 2: The Plot of Solar Irradiation

The village has roughly 8,000 residents, 800 dwellings, and a few communal centers like schools, churches, and the town hall. The village is a working-class community with residents who perform a variety of jobs and leave the house in the mornings and return in the evenings. The rainy and dry seasons are the only two seasons that Nigeria has throughout the year.

Figures 1 and 2 depict the daily load profile of the community and solar irradiation, respectively. Tables 1, 2, and 3 indicate the community's installations and basic electrical demands.

Table 1: Installations in the Project Site

\begin{tabular}{|l|l|}
\hline Installations & Number in Village \\
\hline Houses & 800 \\
\hline Schools & 2 \\
\hline Churches & 3 \\
\hline Town Hall & 1 \\
\hline Small Shops & 20 \\
\hline Village Water pumping System & 1 \\
& \\
\hline
\end{tabular}


Table 2: DC Electrical load of Each House

\begin{tabular}{|l|l|l|l|l|}
\hline Installation & DC Electrical & Load Rating & Hours of & Energy \\
& Features & $(\mathrm{W})$ & Operation & (Wh/day) \\
\hline 4 bedrooms & $4 \times 8.5 \mathrm{~W}$ bulbs & 34 & 6 & 204 \\
\hline Sitting room & $2 \times 8.5 \mathrm{~W}$ bulbs & 17 & 6 & 102 \\
\hline Kitchen & $8.5 \mathrm{~W}$ bulb & 8.5 & 6 & 51 \\
\hline Bathroom & $8.5 \mathrm{~W}$ & 8.5 & 6 & 51 \\
\hline Balcony & $14 \mathrm{~W}$ & 14 & 6 & 84 \\
\hline Television & $30 \mathrm{~W}$ & 30 & 10 & 300 \\
\hline Stereo & $20 \mathrm{~W}$ & 20 & 4 & 80 \\
\hline Ceiling Fan & $15 \mathrm{~W}$ & 15 & 5 & 3000 \\
\hline Refrigerator & $150 \mathrm{~W}$ & 297 & 20 & 3,947 \\
\hline Total & & 150 & & \\
\hline
\end{tabular}

Table 3: DC Electrical load for Public Installations

\begin{tabular}{|c|c|c|c|c|}
\hline Installation & $\begin{array}{l}\text { Electrical } \\
\text { features }\end{array}$ & $\begin{array}{l}\text { Load } \\
\text { Rating (W) }\end{array}$ & $\begin{array}{l}\text { Hours } \\
\text { of operation }\end{array}$ & $\begin{array}{l}\text { Energy } \\
\text { (Wh/day) }\end{array}$ \\
\hline Schools (2) & $\begin{array}{l}2(10 \times 8.5 \mathrm{~W} \\
\text { bulbs })+ \\
(2 \times 8.5 \mathrm{Wbulbs})\end{array}$ & 187 & 6 & 1122 \\
\hline Churches (3) & $\begin{array}{l}3(10 \times 8.5 \mathrm{~W} \\
\text { bulbs })\end{array}$ & 255 & 4 & 1020 \\
\hline Town hall & $4 \times 8.5 \mathrm{~W}$ bulbs & 34 & 3 & 102 \\
\hline Small shops (20) & $\begin{array}{l}20 \times 8.5 \mathrm{~W} \\
\text { bulbs }\end{array}$ & 170 & 12 & 2040 \\
\hline $\begin{array}{l}\text { Village water Pumping } \\
\text { system (1) }\end{array}$ & $1000 \mathrm{~W}$ & 1000 & 2 & 2000 \\
\hline Total & & 1,646 & & 6,284 \\
\hline
\end{tabular}

Table 2 shows that each house has a peak load of $0.30 \mathrm{~kW}$, which adds up to $238 \mathrm{~kW}$ when all 800 houses are taken into account.

The village also contains several public facilities in addition to the dwellings. The village's total peak load is the sum of the power used by all household appliances and public facilities. As seen below, this is calculated:

House Peak + Community Peak = Global Village Consumption 
The load profile does not include heating and cooking because the hamlet uses traditional heating and cooking methods. In a typical Nigerian home, peak power usage occurs in the afternoons between 16.00 (4 p.m.) and 22.00 (10 p.m.), when the neighborhood is at full capacity. As a result, electricity consumption in the morning and afternoon will be low. The village's overall energy consumption per day is $3.16 \mathrm{MWh}$. The village receives an average solar irradiation of $4.7 \mathrm{kWh} / \mathrm{m} 2 /$ day, indicating the potential for good energy from the area's solar resources.

\subsection{Battery Sizing}

In a micro-grid, the storage system is critical. This system is used to store surplus energy produced by the generation system, which is subsequently used to power the micro-grid on days when output is low. The capacity of the battery is determined by:

$$
\begin{aligned}
& \text { Etotal }=\frac{\text { Eday }}{\text { Inverter eff } .} \\
& \text { Etotal }=\frac{3160 \mathrm{kWh}}{0.95}=3326 \mathrm{kWh}
\end{aligned}
$$

Where Eday is the energy need of the community for a day.

The battery capacity is calculated as:

Batt. Cap. $=\frac{\text { Etotal } \times \text { Autonomy Days }}{\text { Bus Voltage } \times \text { Batt.Eff. } \times \% \text { DOD }}=\frac{3160000 \times 1}{360 \times 0.8 \times 0.5}=21,944 \mathrm{Ah}$

Therefore, number of batteries in series is given as:

$N s=\frac{\text { Bus Voltage }}{\text { Battery Nominal Voltage }}=\frac{360}{12}=30$ batteries in series

Number of batteries in parallel is given by:

$N p=\frac{\text { Total Battery Size }}{\text { Rating of Battery }}=\frac{21944}{140}=157$ batteries in parallel

\subsection{System Overview and Description}

The proposed stand-alone DC micro-grid power system consists of the following:

$>$ A PV array for trapping energy from the sun.

$>$ A battery storage system to supply needed power in days of low renewable resources.

$>$ Boost converter.

$>$ Buck converter

The proposed system's goal is to supply and satisfy the Ukubie community's electrical needs by utilizing a high percentage of renewable energy sources and a battery storage system. Because no standard for DC voltage levels has been established, a $360 \mathrm{~V}$ DC bus voltage was used for the system's power distribution. This decision was made after extensive research revealed that the 360VDC is appropriate for long-distance community distribution and also suits the high amount of electricity that would be delivered across the community while also reaching the required safety level. The system used a 24-volt low-voltage direct current (24VLDC) in-house distribution line that is safe for residential use, as well as a 48-volt low-voltage direct current (48VLDC) for the community water pumping system. Figure 3 depicts the block diagram of the proposed stand-alone DC micro-grid. 


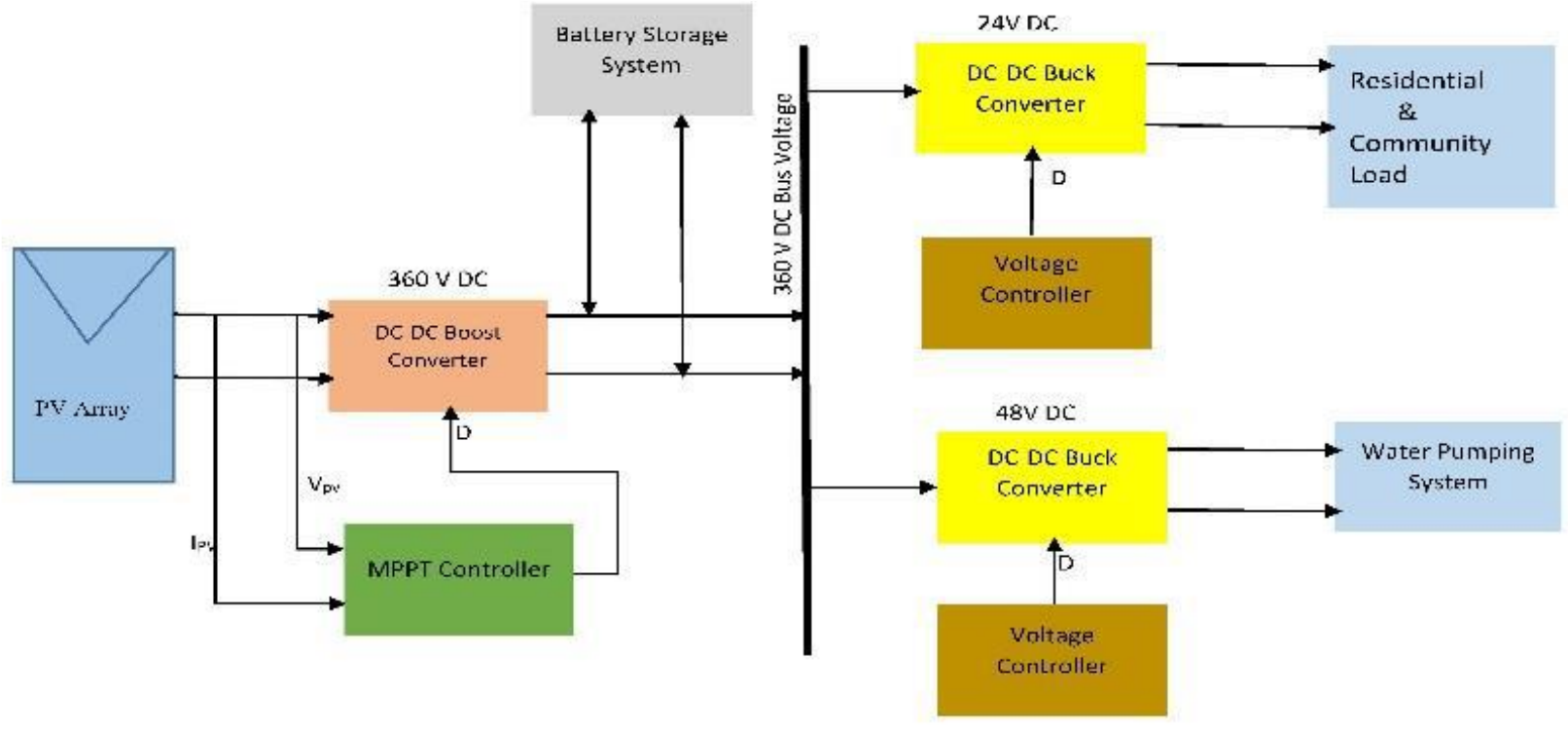

Figure 3: Proposed stand-alone PV Based DC micro-grid block diagram

\subsection{Solar PV Model}

As illustrated in figure 4, the PV module sample model consists of a photocurrent source, a diode, and an internal resistance.

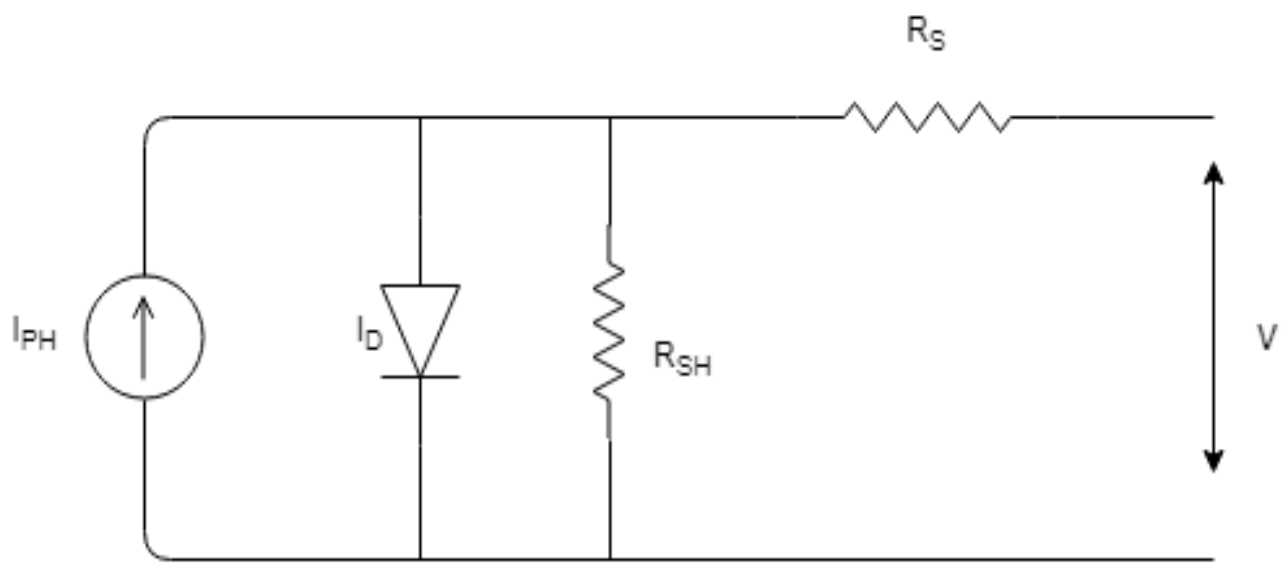

Figure 4: Model of a Solar PV Module

The current obtained from the PV module is given by:

$I=\mathrm{I} P H-\mathrm{I} D=\mathrm{I} P H-I o\left(\exp \left[\frac{e(V+I R s)}{K T c}\right]-1\right)-\left(\frac{V+I R s}{R s h}\right)$

Also, for low internal power dissipation, it's important to remember that shunt or parallel resistors will be larger than the load resistance, which can lead to the two resistances being overlooked when calculating the current, I, as the difference between the photocurrent $I_{P H}$ and the diode current $\mathrm{I}_{\mathrm{D}}$, as shown in equation 3.6.

$I=\mathrm{I} P H-\mathrm{I} D=\operatorname{Io}\left(\exp \left[\frac{\mathrm{eV}}{K T c}\right]-1\right)$ 
Where $K=$ Boltzmann Constant, Tc $=$ Absolute Cell Temperature, $e=$ electronic charge, $V=$ Voltage across cell, $I_{O}=$ Dark saturation current.

The fixed PV array has a $6.84 \mathrm{~kW}$ minimum array size. This PV array has 24 modules per array, with 416 modules per string connected in series and 8 strings connected in parallel. Each $300 \mathrm{~W}$ solar panel is made up of 72 PV cells that are linked in series. Table 4 lists the specifications of the solar module used in this investigation.

Table 4. PV Module Electrical Specification

\begin{tabular}{|l|l|}
\hline Electrical Specification & Value \\
\hline Cells Per Module & 72 \\
\hline Module Efficiency & $15.21 \%$ \\
\hline Power Output Tolerance & $0 /+3 \%$ \\
\hline Maximum Power Voltage & $37.5 \mathrm{~V}$ \\
\hline Maximum Power Current & $8.00 \mathrm{~A}$ \\
\hline Open Circuit Voltage -Voc & $46 \mathrm{~V}$ \\
\hline Short Circuit Current & $8.44 \mathrm{~A}$ \\
\hline Peak Power Watts - Pmax & $300 \mathrm{~W}$ \\
\hline
\end{tabular}

The I-V curve and P-V curves of the BOSH ENERGY c-Si M72 NA41126 300Wp panel under 400, 600, 800, and $1000 \mathrm{~W} / \mathrm{m}^{2}$ solar radiation are presented in figure 5 .

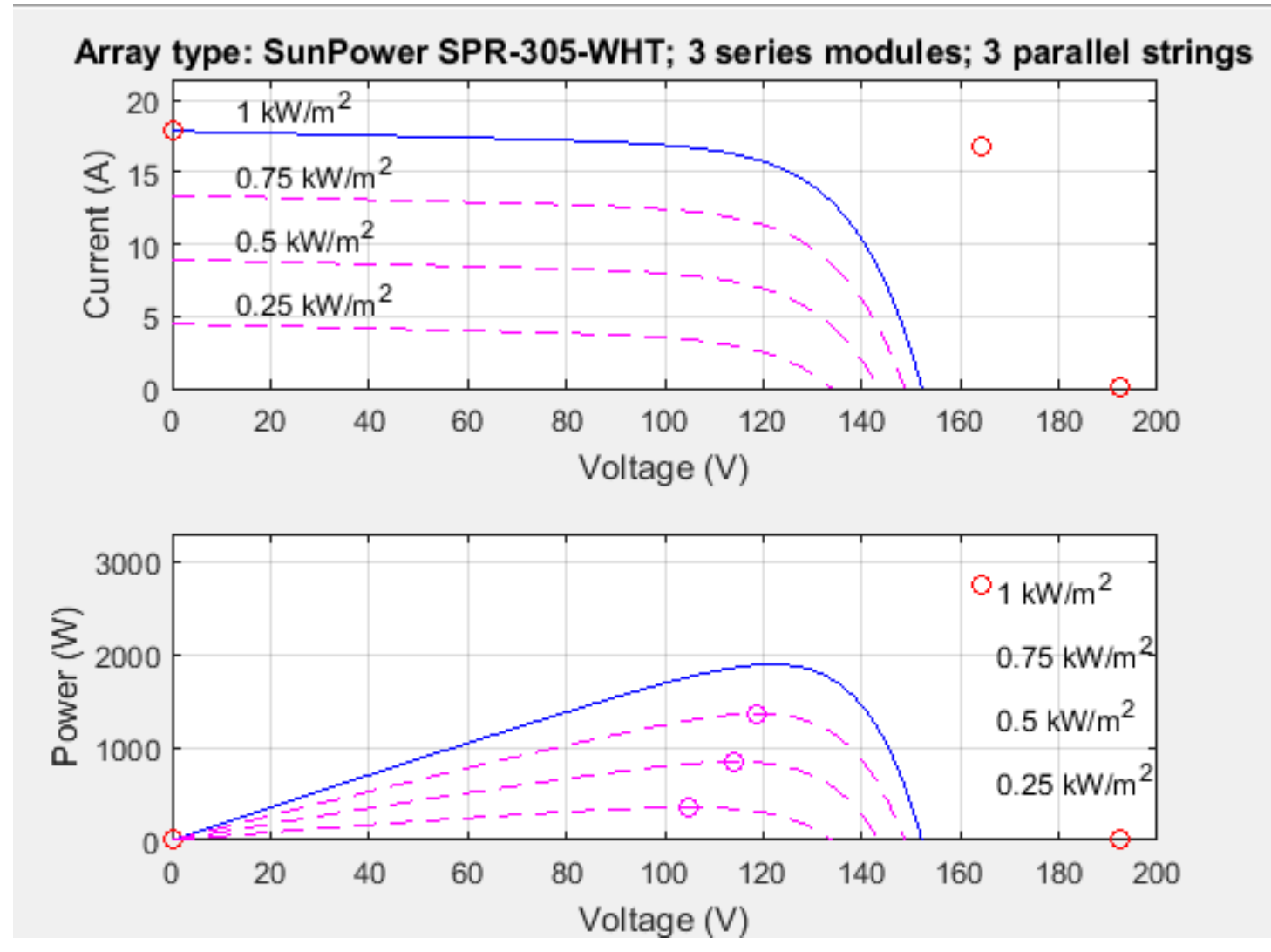

Figure 5: I-V and PV curve of the 300W PV module 


\subsection{Battery Storage Design}

The life duration and capacity of a battery storage system are primarily determined by the rate of discharge, depth of discharge, and temperature. Because of its simplicity and availability in the African market, the Lead-Acid battery technology is used in this project. Furthermore, the Lead-Acid battery is more temperature tolerant and, as a result, will perform well in Africa's hot climate. In microgrids, battery systems are typically used to deliver energy needs to loads at times when renewable energy sources produce low amounts of electricity.

The battery storage system is also used to smooth out voltage changes that occur as a result of the renewable energy sources' intermittent nature. Table 5 lists the specifications for the battery storage system.

Table 5. Stand-Alone DC micro-grid Battery Storage Parameters

\begin{tabular}{|l|l|}
\hline Electrical Specification & Value \\
\hline Nominal Voltage (V) & $360 \mathrm{~V}$ \\
\hline Rated Capacity (Ah) & $21,944 \mathrm{Ah}$ \\
\hline Maximum Capacity (Ah) & $22,858.3 \mathrm{Ah}$ \\
\hline Initial state of Charge (\%) & $70 \%$ \\
\hline Cut off Voltage (V) & $270 \mathrm{~V}$ \\
\hline Capacity at Nominal Voltage (Ah) & $6,808.7 \mathrm{Ah}$ \\
\hline
\end{tabular}

\subsection{DC-DC Boost Converter}

The DC-DC boost converter's job is to stabilize and step up (boost) the unregulated voltage generated by the PV system. The DC-DC boost converter in this micro-grid raises the PV voltage to the $360 \mathrm{~V}$ bus voltage required for transmission and charging the battery system. Figure 6 depicts the boost converter's comparable circuit diagram. The output voltage and current of the converter can be calculated using equations (3) and (4), as shown in the circuit diagram.

The duty cycle, D, and the input all have an impact on the converter output, as can be seen from the mathematical formulae. As a result, the output can be adjusted by varying the duty cycle while the input remains constant.

$V o=\frac{1}{(1-D) \times V i}$

$I o=\frac{1}{(1-D) \times I i}$

Where $D=$ Converter duty Cycle, Vo $=$ Output Voltage,Vi $=$ Input Voltage, $I_{O}=$ Output current and $I_{i}=$ Input Current 


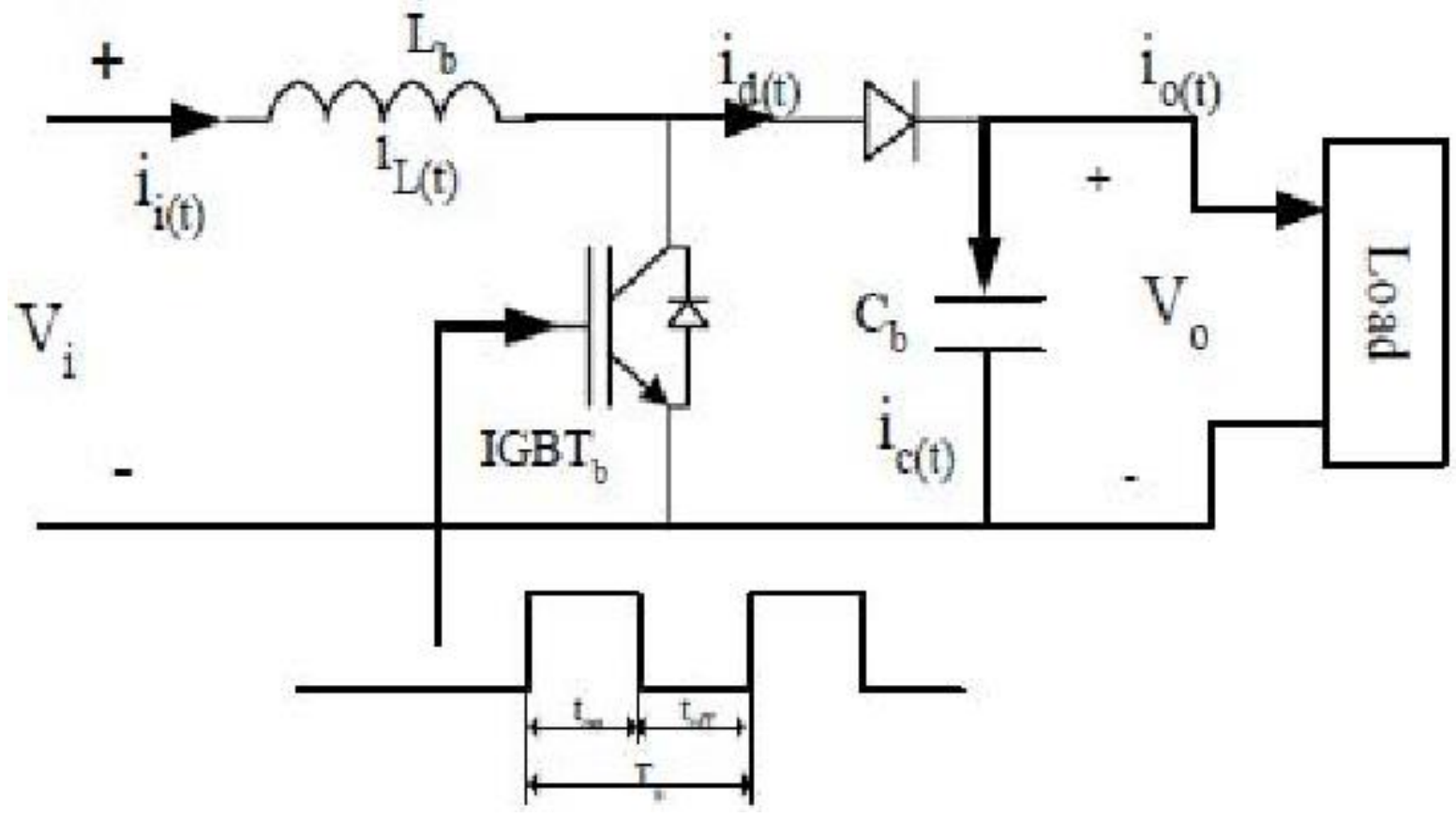

Figure 6: DC-DC Boost Converter Circuit Diagram

\subsection{DC-DC Buck Converter}

Different levels of voltage were required for use at the load end, such as residential buildings and the water pumping system, in the DC micro-grid. The DC-DC buck converter was used to reduce the voltage from the bus to low voltages of 24VDC and 48VDC, which were subsequently fed to the residences and the water pumping system, respectively. Figure 7 depicts the circuit diagram for the buck converter.

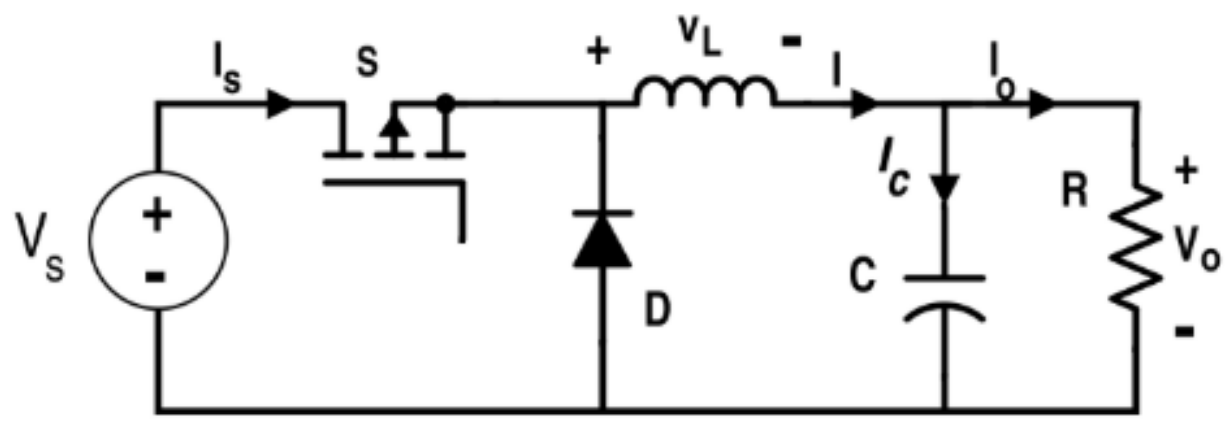

Figure 7: DC-DC Buck converter

The output voltage of the DC-DC buck converter can be obtained using equations (3.9). Also, the buck converter is known to increase the current while stepping down the voltage.

$V o=D \times V i$

Where $D=$ Converter duty Cycle, $V O=$ Output Voltage, $V i=$ Input Voltage. 


\subsection{MPPT Controller}

The PV system operates as illustrated on the I-V characteristics at each point an Operating Point (OP), which is strongly dependent on the available irradiance and temperature, affecting the amount of power that can be harvested from the PV module. As a result, without any external control, the PV module will only produce power as a direct result of changes in irradiance and temperature. Hence the intermittent nature of the power produced.

Because the maximum operating point must be always maintained, regardless of changing geographical conditions, an external system capable of tracking the numerous maximum points in the I-V characteristic curve must be used. The Maximum Power Tracking System is the name given to this system. Various algorithms can be used to obtain maximum power tracking. The Incremental Conductance MPPT technique is used in this study because it is more efficient and accurate than the traditional Perturb and Observe algorithm.

The method uses the voltage and current from the PV array as input to generate pulses, which are then utilized to adjust the duty cycle D of the DC-DC Boost converter. The solar module properties have no effect on the Incremental Conductance method. Equations (10) and (11) describe this procedure, which is also depicted in Figure 8.

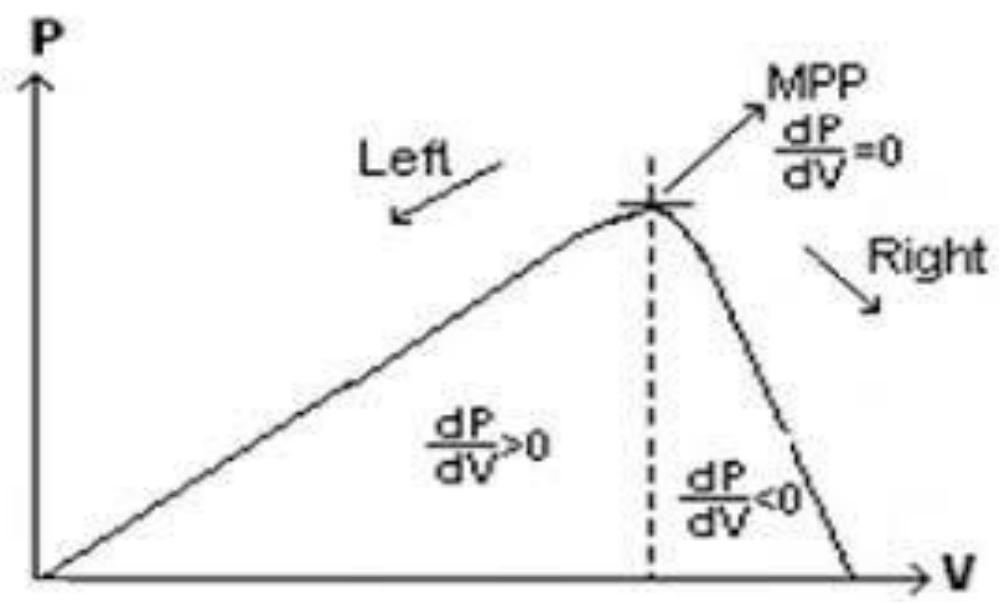

Figure 8: Incremental Conductance MPPT

$P=V \times I$

10

$\frac{d P}{d V}=\frac{d(V \times I)}{d V}=V \times \frac{d I}{d V}+I$

Where $P=$ Power, $V=$ Voltage, $I=$ Current,$d I / d V=$ Conductance. At MPPT, $d I / d V$ or $d P / d V$ must be equal to zero (0).

\subsection{Voltage Mode Controller}

Variations in the system characteristics can have a big impact on the buck converter output voltage. As a result, a control system capable of maintaining constant voltage notwithstanding system distortion is required. The voltage mode controller was used in this research to regulate the suggested system. This is owing to the system's robustness and ease of implementation. Figure 9 depicts the voltage mode controller. The Boost Converter's DC voltage is detected and compared to the configured reference voltage.

Any detected error is fed back to the PI controller as feedback, which is used to generate a voltage that is both constant and very close to the ref voltage. This function is carried out continually by the voltage controller in order to maintain the DC voltage. 


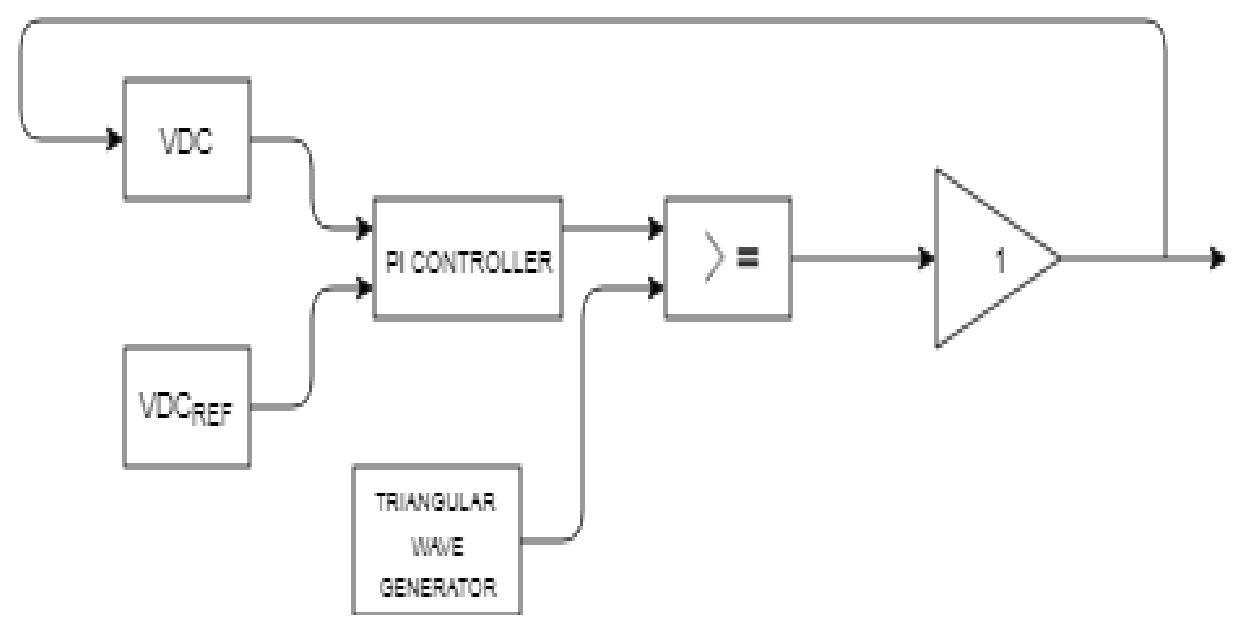

Figure 9: The Voltage Control Block

\subsection{Simulation of the Proposed Stand-Alone PV Based DC Micro-Grid on Simulink}

Simulation is an essential part of every system's design and optimization process. The simulation is carried out for power systems in order to examine the system's instantaneous and timely behavior. This is to see how the suggested system behaves when power quality, voltage stability, and load variation are taken into account. In MATLAB/SIMULINK, the stand-alone DC micro-grid was simulated under a variety of geographic and electrical variables unique to the LOBIA community. The various datasheets of the selected components were also used to obtain parameters for the simulation. Due to the large number of dwellings in the complex, simulating 800 houses on software will be difficult. As a result, all houses were considered to have the same power requirements for the sake of clarity. In Simulink, three (3) dwellings were modeled, and the water pumping system, which operated at a different voltage level, was modeled in a separate branch. On another branch, the rest of the community load was likewise simulated. The current behavior was also noticed since the loads were represented in Simulink with resistor values that corresponded to the power requirements of each load. Despite the fact that the last branch had a lot of current, it was simply included for simulation purposes and would be split during physical development. Figure 10 depicts the DC micro-entire grid's MATLAB/SIMULINK model.

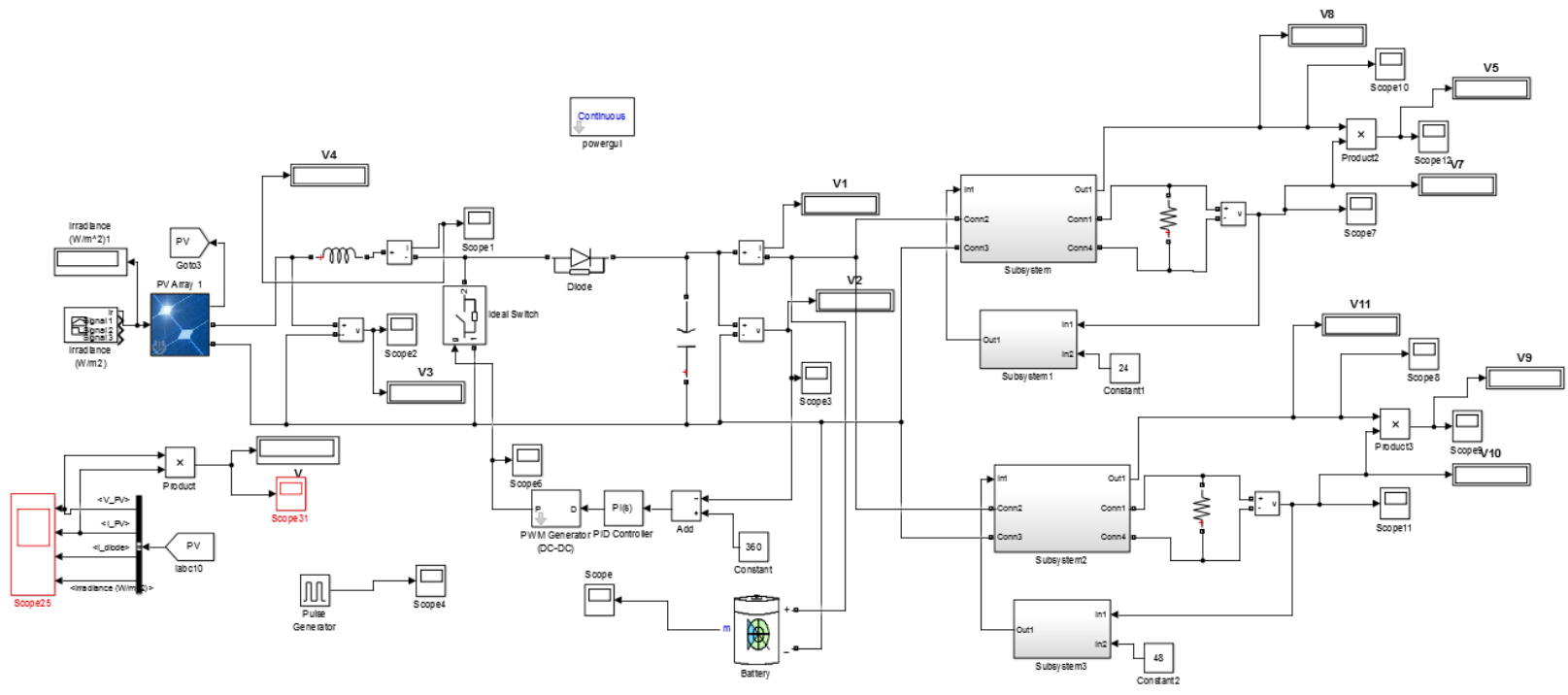

Figure 10: MATLAB/SIMULINK model of the stand-alone PV Based DC micro-grid 


\section{RESULTS}

The Simulink model of the proposed microgrid was simulated for one minute on Matlab/Simulink software, yielding the following relevant results, which are detailed in the subsections below.

\subsection{DC-DC Boost Converter Output Voltage}

The output voltage of a DC-DC boost converter is shown in figure 11. It shows how the PV system's output voltage is boosted to the system's projected 360VDC bus voltage.

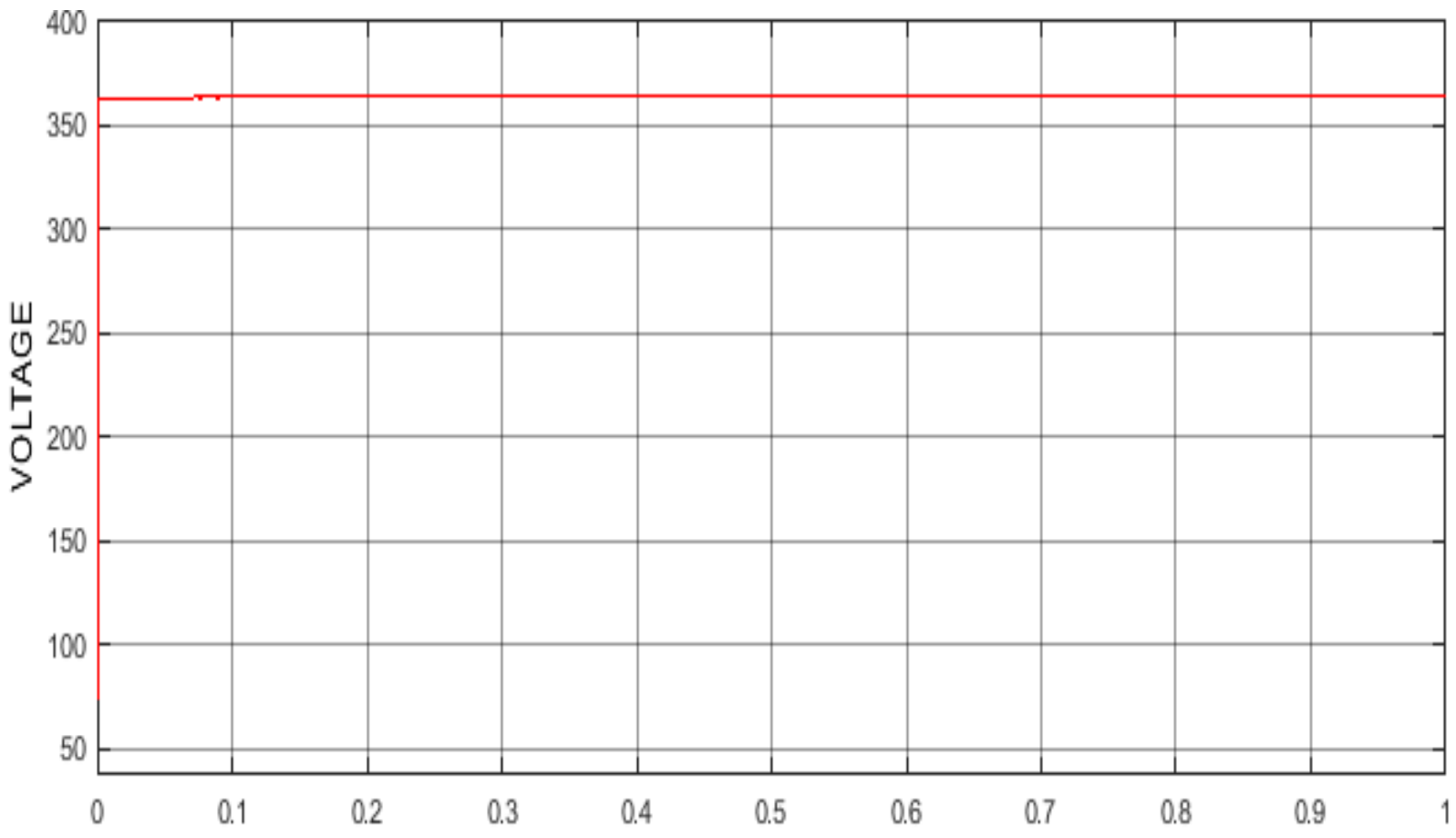

Figure 11: DC-DC Boost Converter Output Voltage

The output voltage of a DC-DC boost converter is shown in figure 11. It shows how the PV system's output voltage is boosted to the system's projected 360VDC bus voltage.

\subsection{Voltage and Current Output for Water pumping facility}

The display of the community water pumping system, which had its voltage stepped down to 48VDC to meet the voltage requirement of the chosen water pumping equipment is shown in figures 12 and 13 respectively. The current was also displayed as shown. 


\section{LOAD VOLTAGE}

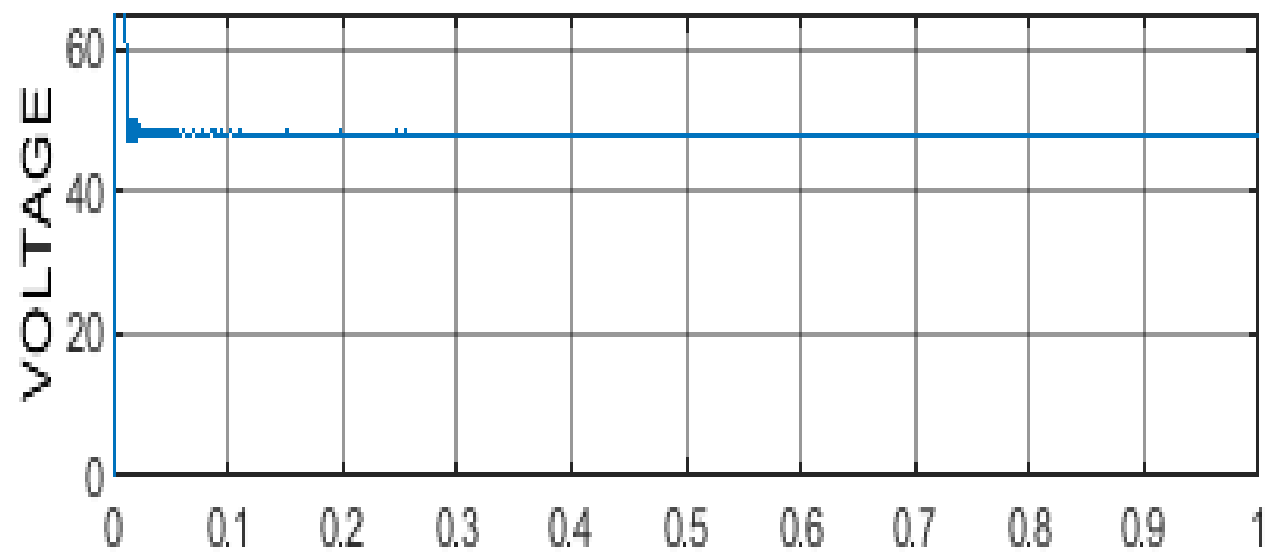

Figure 12: Output Voltage for Water pumping facility
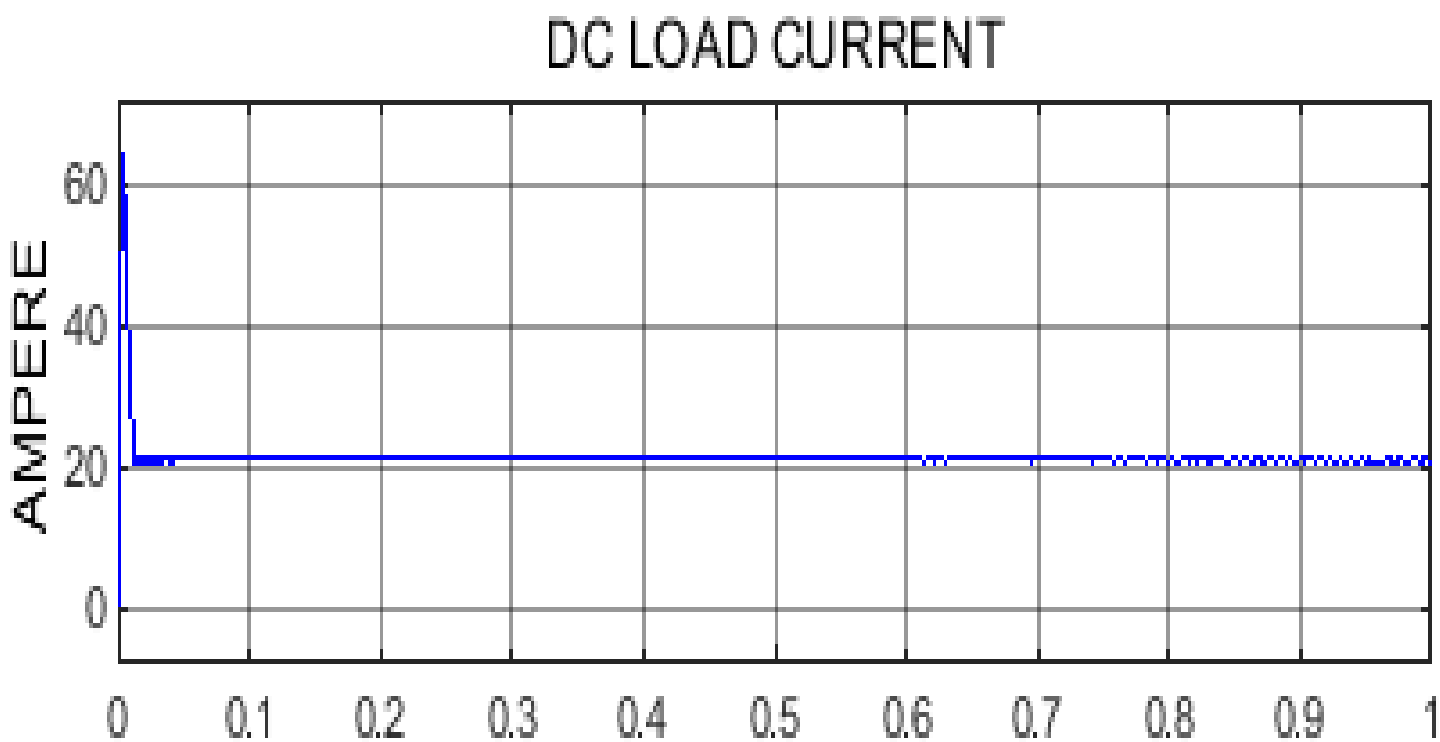

Figure 13: Output Current for Water pumping facility

\subsection{Voltage and Current Output for Residential House}

Figures 14 and 15 show the load linked to a single residential house, with the voltage stepped down to $24 \mathrm{~V}$ for domestic usage by the buck converter. In addition, the current was displayed. The $24 \mathrm{~V}$ was proposed for domestic use in order to handle some high-voltage gadgets. 
DC LOAD VOLTAGE

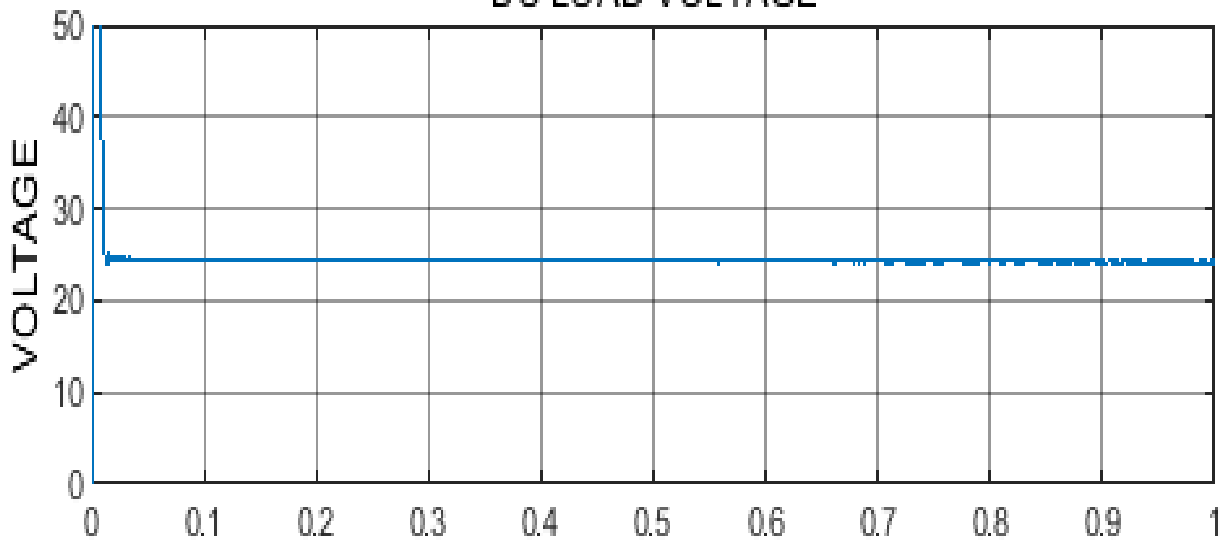

Figure 14 Output Voltage for Residential House

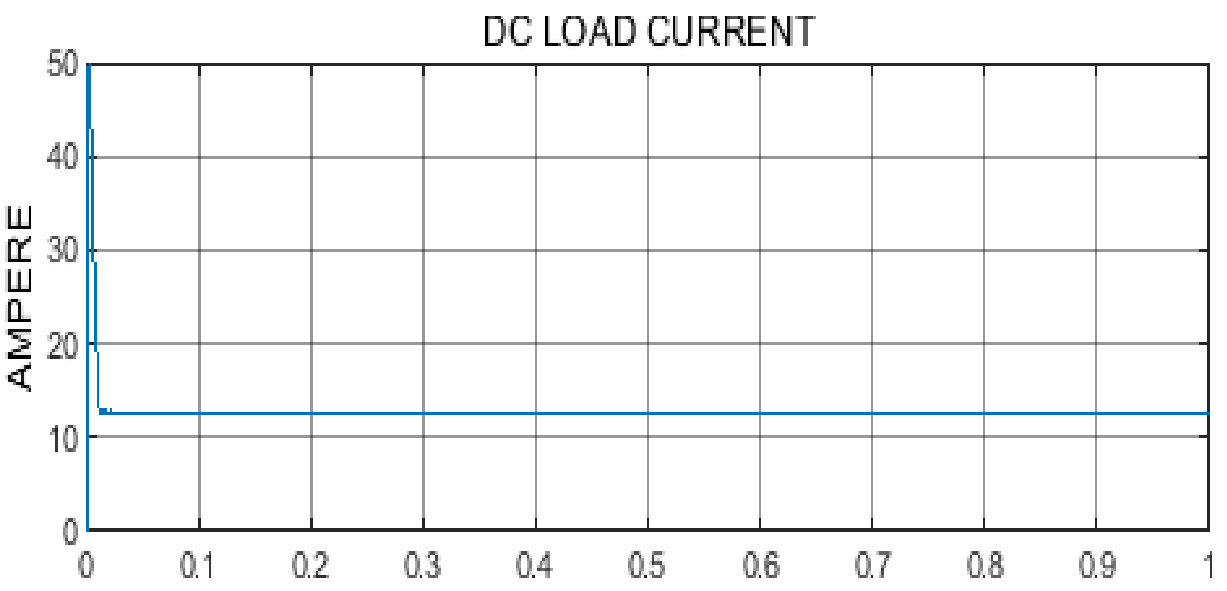

Figure 15 Output Current for Residential House

The voltages were of constant value on all voltage monitors, indicating that the voltage mode controller was properly functioning to retain the load voltages at the required voltage levels notwithstanding any impact from the loads. 


\subsection{Solar Irradiance}

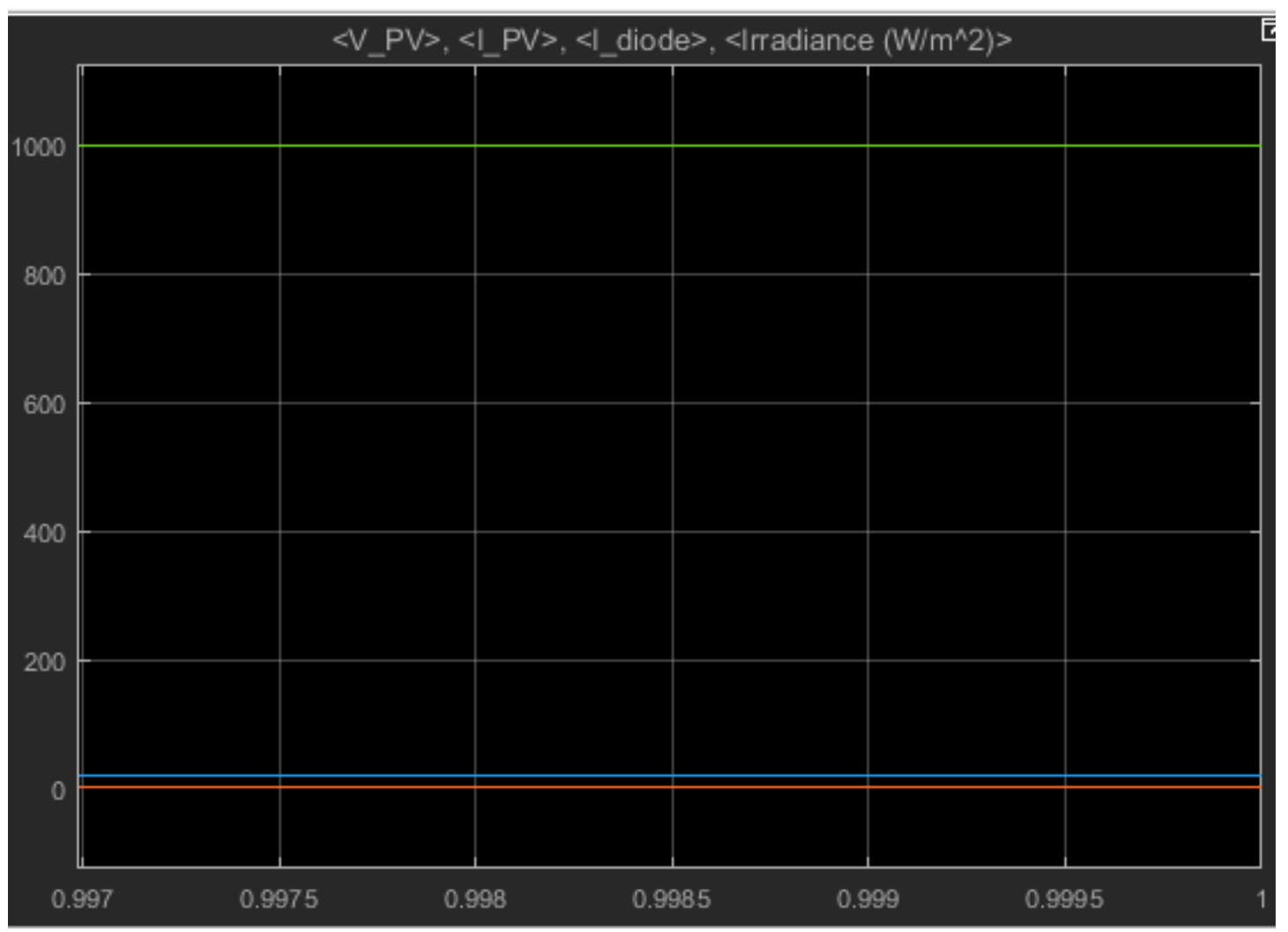

Figure 16: Solar Irradiance

The solar irradiation at which the PV system is operating is shown in figure 16. The PV generated power is also shown in the graph, with a value that is quite near to $1000 \mathrm{~kW}$. 


\subsection{Battery System Voltage and State of Charge}
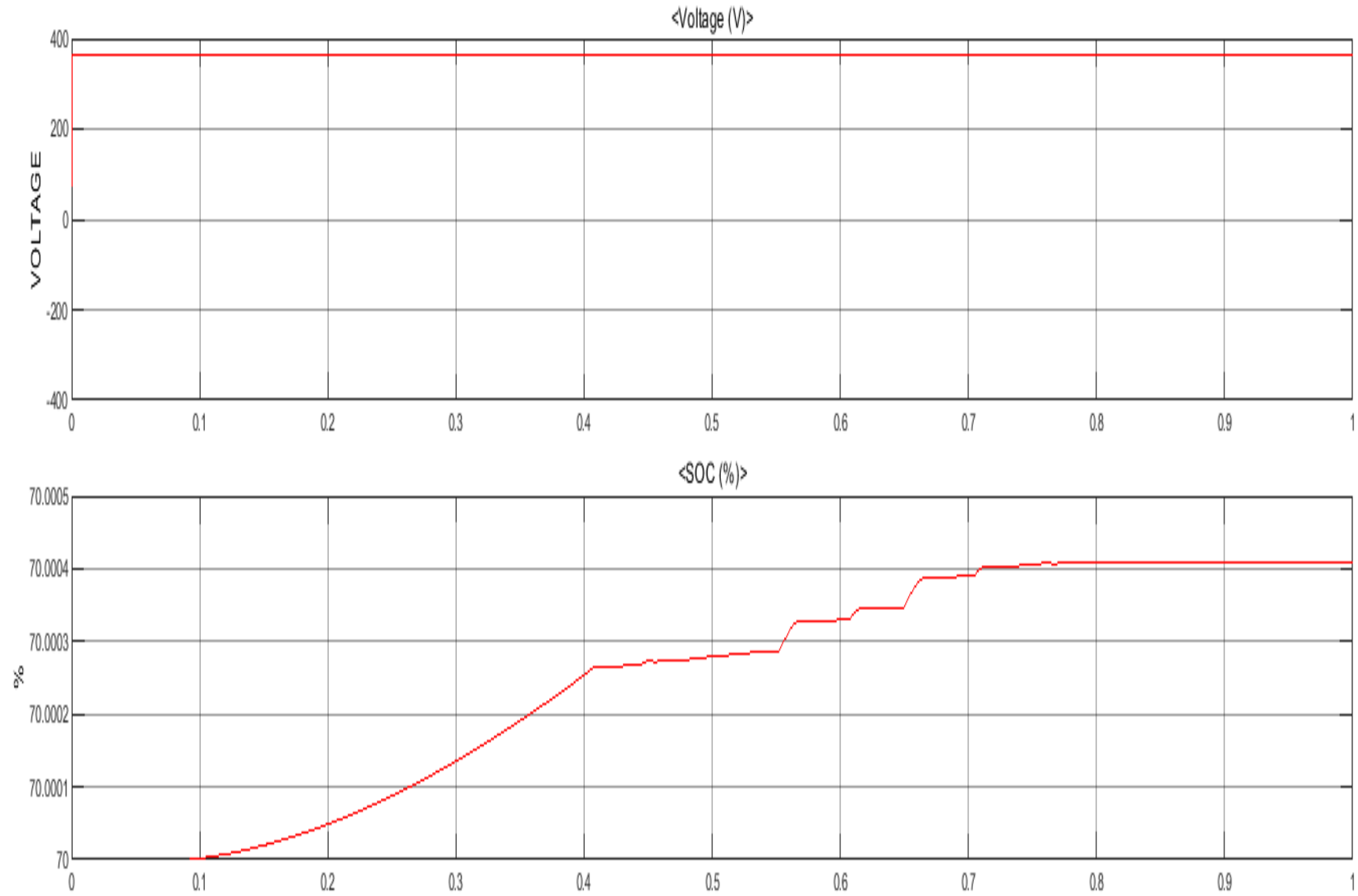

Figure 17: System Battery Voltage and State of Charge

In figure 17 , the voltage of the battery storage system is shown as $360 \mathrm{~V}$. This means that the battery system can use the system bus voltage to power the system. Furthermore, the image illustrates the state of charge of the battery system as it climbs from the simulation's beginning level of charge of $70 \%$. During periods of high irradiation, this increase in the level of charge indicates that both the battery and PV systems are being charged. 


\section{CONCLUSION}

Due to the lack of access to national grid in Lobia community Bayelsa State, design and simulation of a stand-alone PV based DC micro-grid for the community was examined. The system was modeled and simulated in MATLAB/Simulink environment, considering the size of the community, its location, and the various facilities that require electrical energy in the community, as these parameters are critical when proposing a power system for a specific location. The power system that can meet the community's energy requirements (3.16MWh/day) was obtained after knowing the community's energy demand. Simulation outputs, such as constant voltage, maximum power operation, and battery charging, depicted a very functional and feasibly independent power system capable of standing as a solution to the community's long period without electricity because it can comfortably meet its energy requirements. In the future, a comparison of the current storage system, which is a lead-acid battery, and a storage system based on ultra-capacitors, can be done to see the differences in behavior and determine which storage system is better for the DC microgrid.

\section{ACKNOWLEDGMENT}

This research work was supported financially Dr. Nimibofa Ayawei.

\section{REFERENCES}

[1] S. Lee, "Implementation of a DC Microgrid." PhD diss., 2017.

[2] A. T. Elsayed, A. A. Mohamed, and O. A. Mohammed. "DC microgrids and distribution systems: An overview." Electric power systems research 119 (2015): 407417.

[3] R. Seung-Hee, J. Ahn, B. Lee, and K. Cho. "Single-switch ZVZCS quasi-resonant CLL isolated DC-DC converter for low-power 32 "LCD TV." In 2013 IEEE Energy Conversion Congress and Exposition, pp. 4887-4893. IEEE, 2013.

[4] V. K. Prasad. "Feasibility of DC microgrids for rural electrification." (2017).

\section{AUTHORS}

First Author - Ayibapreye Kelvin Benjamin, Ph. D in Computing and Electronic Systems University of Essex, United Kingdom, M.Sc. in Electronic Communications and Computer Engineering, The University of Nottingham, United Kingdom, B.Eng. Electrical/Electronic Engineering, Niger Delta University, Nigeria, Niger Delta University, Wilberforce Island Bayelsa State, Nigeria. ayibapreyebenjamin@ndu.edu.ng

Second Author - Engr. Christopher Akemi is an M.Sc. candidate in the Department of Electrical/Electronic Engineering, Faculty of Engineering, Niger Delta University, Wilberforce Island, Bayelsa State, Nigeria. chrisebibo@ gmail.com

Third Author - Aguiyi Nduka Watson, M.Eng. in Electrical Engineering, Rivers State University, Nigeria, B.Eng. Electrical Engineering, Rivers State University, Nigeria, Federal University Otueke, Bayelsa State, Nigeria. aguiyiwatson@gmail.com

Correspondence Author - Ayibapreye Kelvin Benjamin, Ph. D in Computing and Electronic Systems University of Essex, United Kingdom, M.Sc. in Electronic Communications and Computer Engineering, The University of Nottingham, United Kingdom, B.Eng. Electrical/Electronic Engineering, Niger Delta University, Nigeria, Niger Delta University, Wilberforce Island Bayelsa State, Nigeria. ayibapreyebenjamin@ndu.edu.ng, contact number: +2348166924395 